\title{
MENINGKATKAN KOSAKATA BAHASA INGGRIS SISWA SD
}

\author{
Buasim
}

\begin{abstract}
Mastering vocabulary is one of the essential competencies in using any language and developing vocabulary in a foreign language becomes one of the problems faced by the teacher in teaching a foreign language particulary for the beginners. Based on the existing problems and condition, this action research attempted to solve the problem. The research took place in a Government Primary School located in Tegal Parang, Jakarta, named SDN Tegal Parang 06 Pagi, Mampang Prapatan. The researcher overcame the problem in developing English vocabulary of the fourth grade of the school by using songs and media. After three cycles of practicing the action research procedures and steps, the English vocabulary of the studens was improved significantly. This research concludes, using songs and appropriate media can overcome the difficulties in developing the fourth grade students' vocabulary in SDN Tegal Parang 06 Pagi.
\end{abstract}

Keywords: action research, vocabulary, competency, songs, media.

\section{PENDAHULUAN}

Kebutuhan terhadap kemampuan berbahasa Inggris tampaknya akan menguat terus, sejalan dengan proses globalisasi yang saat ini telah bergulir dan merambat ke berbagai negara di seluruh dunia. Kemampuan berbahasa Inggris dibutuhkan dalam era globalisasi karena bahasa Inggris diakui sebagai bahasa internasional yang dapat digunakan sebagai alat komunikasi utama dalam kehidupan global.

Kemampuan berbahasa Inggris, di samping merupakan alat yang memungkinkan seseorang melakukan komunikasi di era globalisasi, pada batas tertentu, bahasa Inggris juga merupakan faktor yang menentukan kemajuan dan kesuksesan seseorang. Hal ini dapat dipahami karena banyak segi dari kemajuan ilmu pengetahuan dan teknologi yang dituangkan ke dalam bahasa Inggris sehingga dibutuhkan kemampuan berbahasa Inggris untuk dapat mengaksesnya.

Pentingnya kemampuan berbahasa Inggris telah lama disadari oleh para pengambil kebijakan dalam dunia pendidikan. Hal ini dapat dilihat dari dicantumkannya bahasa Inggris sebagai bidang studi yang diajarkan di Sekolah Dasar (SD), walaupun masih ditawarkan sebagai muatan lokal. Di kota-kota besar, khususnya di DKI Jakarta, pelajaran bahasa Inggris ini diajarkan sebagai mata pelajaran wajib, meskipun penerapannya masih beraneka ragam. Hal ini boleh jadi disebabkan karena kesadaran terhadap pentingnya kemampuan berbahasa Inggris tampaknya lebih besar dirasakan oleh masyarakat perkotaan.

Ada beberapa persoalan yang dihadapi ketika SD mulai memberlakukan pelajaran bahasa Inggris di sekolahnya. Persoalan yang dianggap paling mendasar adalah belum tersedianya tenaga pemelajar yang memadai. Persoalan ini terus berlanjut sampai saat ini dan tampaknya belum ada jalan keluar untuk mengatasinya. Konsekuensinya, sekolah-sekolah dasar memiliki cara-cara yang berbeda dalam menyediakan tenaga pemelajar bahasa Inggris. Ada yang ditangani oleh guru kelas atau merekrut tenaga dari luar sebagai guru honorer.

Kemampuan guru dalam membelajarkan bahasa Inggris di sekolah dasar masih mengundang pertanyaan dan keraguan banyak pihak, baik yang menyangkut tentang penguasaan materi atau metode penyampaiannya. Hal ini disebabkan karena sesungguhnya mereka bukan tenaga profesional yang dikhususkan untuk mengajar bahasa Inggris di SD. Sebagai konsekuensinya, bergulir isu di masyarakat bahwa pembelajaran bahasa Inggris di SD belum memadai. Ada angin segar bahwa dalam UndangUndang (UU) Guru dan Dosen No. 14 tahun 2005 Tentang Kebijakan Baru yang menyatakan bahwa para guru SD sudah harus berkualifikasi S1, khususnya pada S1 bidang ke-SD-an. Pemerintah juga mempersiapkan tenaga pemelajar bahasa Inggris yang berkualifikasi S1. Hal ini senada dengan yang ditulis di dalam koran Kompas pada tangal 17 September 2006, bahwa guru SD-SLTP diusulkan minimal S1dan di dalamnya ditulis juga tentang fenomena para guru SD di Indonesia yang jumlahnya selalu kurang serta masih belum bisa melakukan inovasi-inovasi dalam pembelajaran. Hal ini tentunya menjadi masukan dan pekerjaan rumah bagi para pengambil kebijakan, khususnya di bidang pendidikan.

Dari uraian tersebut di atas, penulis akan mencoba melakukan perbaikan proses pembelajaran 
khususnya dalam mata pelajaran bahasa Inggris bagi guru-guru SD di wilayah DKI Jakarta sehingga mempunyai ciri khas yang menjadi barometer keberhasilan bagi daerah-daerah lain di Indonesia.

Untuk itu penulis akan mengaplikasikan pendekatan pembelajaran yang sesuai dalam membelajarkan bahasa Inggris di kelas IV SDN Tegal Parang 06 Pagi di Mampang Prapatan, Jakarta Selatan dengan menggunakan pendekatan nyanyian dibantu dengan media gambar yang dapat meningkatkan jumlah kosakata bahasa Inggris.

Fokus permasalahan dari penelitian ini ialah Teaching English Through Songs and Media: Upaya Meningkatkan Jumlah Kosakata Bahasa Inggris untuk Anak Kelas IV SDN Tegal Parang 06 Pagi di Jakarta Selatan. Untuk memahami berbagai konsep teoretis yang mendukung permasalahan tersebut maka akan dibahas tentang beberapa teori yang melandasi permasalahan di atas.

\section{KAJIAN TEORETIS}

\section{Hakikat Belajar}

Dalam proses belajar membelajarkan, peranan guru yang utama ialah menciptakan suasana belajar yang dapat memotivasi siswanya untuk senantiasa belajar dengan baik dan bersemangat. Dengan suasana belajar membelajarkan yang menantang berkompetisi secara sehat, diharapkan akan berdampak positif dalam pencapaian prestasi hasil belajar yang optimal.

Sehubungan dengan uraian proses belajar membelajarkan di atas maka akan dikemukakan hakikat belajar tersebut. Winkel (1991:36) menyatakan bahwa belajar ialah suatu aktivitas mental atau psikis. Perubahan itu bersifat secara relatif konstan dan berbekas. Sedangkan Morris (1990: 178) mengatakan bahwa belajar merupakan suatu proses yang luas, di mana pengalaman yang menghasilkan perubahan tingkah laku yang relatif permanen.

\section{Hakikat Nyanyian}

Dalam proses belajar membelajarkan, peran seorang guru sangat penting dan menentukan. Untuk itu, guru harus dapat memilih pendekatan dan metode yang cocok dan sesuai untuk anak didiknya. Agar dalam proses belajar membelajarkannya menarik dan menyenangkan, khususnya membelajarkan Bahasa Inggris untuk anak-anak SD, guru harus selalu menyiapkan alat peraga atau media yang sesuai, lagulagu yang membuat anak didik senang, menikmati atau enjoy dan tidak merasa bosan dalam belajar Bahasa Inggris.
Subyakto (1986:5) mengatakan bahwa pendekatan adalah gagasan yang mendasari pengkajian atau usaha belajar sesuatu keterampilan atau suatu ilmu pengetahuan sedangkan pengertian metode adalah cara yang telah teratur dan terpikir baik-baik untuk mencapai sesuatu maksud. Di sini, istilah metode dipakai dalam arti seperangkat cara membelajarkan yang telah teratur dan tersusun baik berdasarkan suatu pendekatan yang telah dirumuskan.

Dalam pelaksanaan proses belajar membelajarkan di kelas, seorang guru dituntut dapat menciptakan suasana belajar yang kondusif, menantang, dan menyenangkan. Oleh karena itu, guru harus menggunakan nyanyian karena semua anak seusia anak SD senang bernyanyi. Hal ini sesuai dengan GBPP Bahasa Inggris Muatan Lokal (1993:3), dalam salah satu rambu-rambunya mengatakan bahwa dalam proses pembelajarannya harus menggunakan alat peraga dan bernyanyi. Sebagai konsekuensinya guru harus menggunakan lagu-lagu atau nyanyian dalam membelajarkan bahasa Inggris karena melalui nyanyian anak-anak merasa senang dan tidak bosan dalam belajar bahasa Inggris. Hanlon (2004:vii) mengatakan: "...We therefore strongly promote singing and role-playing as effective, entertaining methods for learning." Artinya ialah agar efektif dalam membelajarkan siswa SD, ditekankan untuk menggunakan nyanyian dan bermain peran.

\section{Hakikat Media Pembelajaran}

Dalam proses belajar membelajarkan, peranan media pembelajaran sangat penting karena dengan menggunakan media maka proses pembelajaran itu sendiri akan lebih efektif. Dengan kata lain, media pembelajaran dapat difungsikan sebagai alat bantu untuk mensukseskan kegiatan proses belajar membelajarkan di dalam kelas. Dalam kegiatan pembelajaran, media merupakan pembawa pesan yang berasal dari suatu sumber kepada penerima pesan. Dalam hal ini, sebagai sumber adalah guru dan penerima pesan adalah murid. Hal ini sesuai dengan pendapat Burden dan Byrd dalam bukunya (1999:137) menyatakan: "Instructional media are carriers of information between a source and a receiver" yang artinya, media pembelajaran adalah pembawa informasi dari suatu sumber kepada penerima informasi atau pesan. Selanjutnya, Wibawa dan Mukti (1993:24) menyatakan bahwa media pembelajaran yang sering digunakan dalam kegiatan proses belajar membelajarkan terdiri dari media audio, media visual, media audio-visual, dan media serbaneka. Dalam penelitian tindakan kelas ini akan digunakan media visual, itupun yang dipakai ialah Charts dan Flash 
Cards karena media itu dapat dipadukan dengan nyanyian. Di samping itu, guru dapat membuat media itu sendiri tanpa membeli yang mahal, yang penting guru itu harus kreatif. Dalam praktiknya atau kegiatan proses belajar membelajarkannya, terjadi interaksi antara guru dengan siswanya dengan menggunakan indrawi masing-masing. Siswa, sebagai penerima pesan terangsang oleh media untuk menggunakan alat inderanya untuk menerima pesan. Dengan demikian, siswa dapat mempelajari materi pelajaran dengan memanfaatkan media yang digunakan oleh guru. Untuk itu dalam melaksanakan proses belajar membelajarkan di kelas, guru diharapkan selalu menggunakan media pembelajaran.

\section{METODOLOGI PENELITIAN}

Penelitian ini merupakan penelitian kaji tindak (Classroom Action Research) yang dilakukan di kelas, sehingga lazim disebut sebagai penelitian tindakan kelas. Tujuan penelitian tindakan kelas ini adalah untuk memperbaiki efektivitas dan efisiensi praktis pembelajaran dan lebih fokus lagi adalah dalam upaya meningkatkan kualitas suatu pembelajaran, dalam hal ini adalah di SD. Dengan demikian, peneliti harus melakukan sebuah tindakan atau action agar permasalahan dapat diselesaikan.

Pendekatan Penelitian Tindakan Kelas (PTK) yang mengacu pada model yang dikembangkan oleh Stanford dan Kemmis dalam Tantra (2005:7) yang memiliki tujuan untuk melakukan perbaikanperbaikan terhadap proses pembelajaran berdaur ulang dan bersifat mandiri. Dilaksanakan dengan model siklus, di mana pada setiap siklusnya terdiri dari tahapan-tahapan, yaitu perencanaan (planning), penerapan tindakan (action), observasi, dan evaluasi proses, serta hasil tindakan (observation and evaluating), dan refleksi (reflection). Oleh karena waktu terbatas maka dalam penelitian ini dibatasi sampai tiga siklus saja. Suharsimi menggambarkan daur ulang ini dalam setiap siklusnya (2007: 74) sebagai berikut.

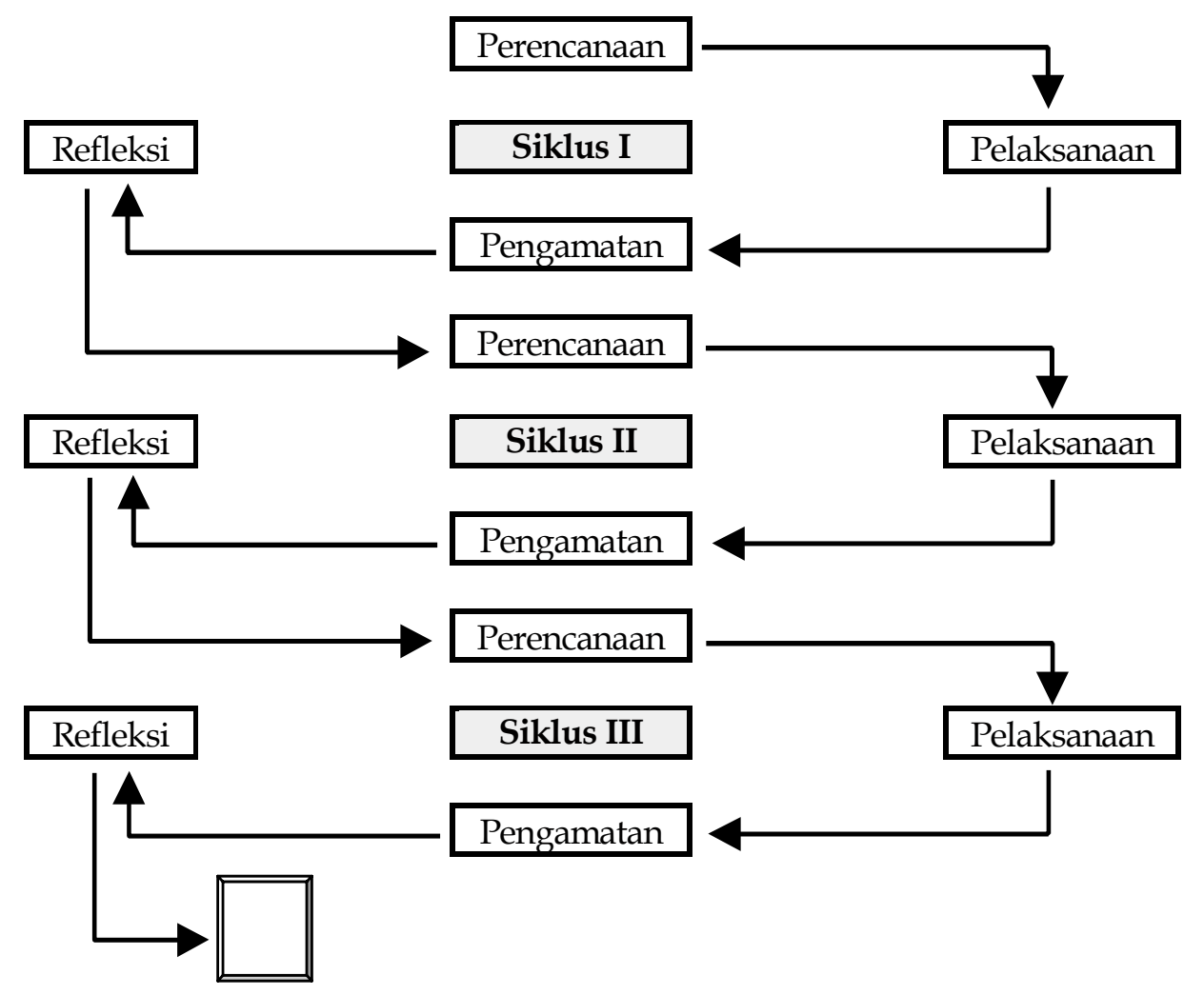

Gambar 1. Pendekatan penelitian tindakan kelas

Dalam penelitan ini terdapat dua aktivitas yang dilakukan secara simultan, yaitu aktivitas tindakan (action) dan aktivitas penelitian (research), demikianlah menurut Rusgianto (1998: 42). Pada pelaksanaannya, kedua aktivitas itu dilaksanakan oleh satu orang atau dua orang berbeda yang saling berkolaborasi.
Penelitian ini melibatkan sebuah tim yang terdiri dari ketua peneliti dan anggota peneliti yang mempunyai tugas masing-masing (seperti yang diuraikan pada personalia penelitian).

Adapun langkah-langkah penelitian adalah sebagai berikut. 


\section{Persiapan penelitian}

Hal-hal yang harus dipersiapkan dalam penelitan ini adalah dosen bersama-sama guru membuat instrumen untuk menginventarisasi sikap siswa selama belajar bahasa Inggris, instrumen untuk guru selama melaksanakan proses pembelajaran, mempersiapkan lagu, dan alat peraga atau media pembelajaran, serta pembuatan soal-soal evaluasi.

2. Pelaksanaan penelitian

\section{Siklus I}

Siklus I terdiri dari dua kali pertemuan, yaitu tanggal 23 dan 25 Juli 2007, masing-masing pertemuan dua jam pelajaran.

a. Perencanaan tindakan

Hal ini diawali dengan observasi guru bahasa Inggris yang sedang membelajarkan dan sikap siswa pada saat guru membelajarkan bahasa Inggris yang dilakukan oleh dosen dan teman sejawat guru pada waktu persiapan penelitian, kemudian bersama-sama berdiskusi tentang hasil observasi dan membuat rencana pembelajaran dengan topik atau pokok bahasan objects in the classroom dengan menggunakan lagu this... and that is dan medianya.

b. Pelaksanaan tindakan

Guru kelas melaksanakan membelajarkan objects in the classroom dengan menggunakan alat peraga dan nyanyian this... and that is.

c. Observasi guru membelajarkan oleh dosen dan teman sejawat

Dosen dan guru teman sejawat melakukan observasi terhadap guru membelajarkan dan diakhiri dengan pemberian tes akhir kepada para siswanya. Instrumen yang digunakan APKG1 dan APKG2, instrumen pemantau tindakan, dan instrumen hasil belajar akhir siklus.

d. Refleksi

Diskusi tim peneliti untuk menentukan tindakan yang akan dilakukan pada langkah selanjutnya berdasarkan temuan refleksi pada saat pelaksanaan tindakan.

\section{Siklus II}

Siklus II terdiri dari dua kali pertemuan, yaitu tanggal 30 Juli dan 1 Agustus 2007, masing-masing pertemuan dua jam pelajaran.

a. Perencanaan tindakan

Dari hasil observasi, evaluasi, dan refleksi pada siklus I, dibuat rencana perbaikan pembelajaran I dengan menggunakan pendekatan melalui nyanyian dan media.

b. Pelaksanaan tindakan

Guru bahasa Inggris melaksanakan proses pembelajaran dengan menggunakan pendekatan melalui nyanyian dan media. Media yang digunakan ialah charts dan flash cards fruits. Dalam pelaksanaannya guru mengucapkan kosakata yang diulang sampai tiga kali dan siswa mendengarkan. Setelah itu guru mengucapkan kosakata itu lagi, dan siswa menirukan. Hal ini dilaksanakan sampai sepuluh kosakata baru yang diulang-ulang. Hal ini dilakukan agar siswa dapat mengucapkan kosakata itu dengan benar. Setelah itu, guru membelajarkan menyanyi dengan kosakata yang sudah diajarkan sebelumnya. Dalam menyanyi ini, harus diulang-ulang sampai anak-anak dapat menyanyikan lagu itu dengan benar. Sebagai variasi dalam membelajarkan, guru dapat menyuruh anak-anak menyanyi perorangan ataupun secara kelompok, hal ini tergantung kepada kreativitas guru di dalam kelas.

c. Observasi guru membelajarkan oleh dosen dan teman sejawat

Mencatat proses pembelajaran guru dalam membelajarkan dan memperhatikan kondisi siswa selama belajar, serta memberikan tes tertulis untuk siswa pada akhir siklus. Instrumen yang digunakan adalah APKG1, APKG2, instrumen pemantau tindakan, dan instrumen hasil belajar akhir siklus. d. Refleksi

Diskusi tim peneliti untuk mendiskusikan dan menentukan tindakan yang akan dilakukan pada langkah selanjutnya.

\section{Siklus III}

Siklus tiga terdiri dari satu kali pertemuan, yaitu tanggal 10 Agustus 2007, setiap pertemuan dua jam pelajaran.

a. Perencanaan tindakan

Dari hasil observasi, evaluasi, dan refleksi pada siklus II maka dibuatlah rencana perbaikan pembelajaran ketiga dengan menggunakan pendekatan melalui nyanyian dan media. Alat peraga yang digunakan ialah charts dan flash cards tentang binatang (animals) sesuai dengan pokok bahasannya.

b. Pelaksanaan tindakan

Membelajarkan bahasa Inggris dengan pendekatan melalui nyanyian dan media, serta alat peraga yang digunakan ialah charts dan flash cards tentang animals.

c. Observasi guru membelajarkan oleh dosen dan teman Sejawat

Observasi terhadap proses pembelajaran, untuk guru dan siswa. Instrumen yang digunakan adalah APKG1, APKG2, instrumen tindakan, dan instrumen hasil belajar akhir siklus. Evaluasi untuk siswa berupa tes tertulis. 


\section{d. Refleksi}

Diskusi tim peneliti untuk menganalisa hasil penelitian. Penelitian diakhiri dengan diberikan tes akhir tentang materi yang telah diajarkan, yaitu tentang animals atau nama-nama binatang dengan bentuk soal matching atau menjodohkan. Selain itu, menyebarkan angket tentang sikap siswa pada saat selesai penelitian untuk mengetahui apakah kualitas pembelajaran bahasa Inggris menggunakan pendekatan melalui nyanyian dan media di SDN Tegal Parang 06 Pagi Mampang Prapatan, Jakarta Selatan sudah meningkat atau belum.

\section{HASIL PENELITIAN}

\section{Persiapan penelitian}

Persiapan yang dilakukan dalam penelitian ini adalah sebagai berikut.

a. Instrumen untuk menginventarisasi sikap siswa selama belajar bahasa Inggris. Hasil inventaris terhadap sikap siswa selama mengikuti pembelajaran bahasa Inggris adalah sebagai berikut.

1) Bagi siswa pelajaran bahasa Inggris tingkat kesulitannya dianggap cukup sulit, kurang disenangi dan kurang menarik meskipun penting dalam kehidupan sehari-hari.

2) Jika disuruh mengerjakan soal yang ada di buku Lembar Kerja Siswa (LKS), siswa raguragu, dan kurang yakin.

3) Jika ada Pekerjaan Rumah (PR), hasilnya siswa tetap ragu-ragu dan tidak yakin.

4) Nilai hasil belajar bahasa Inggris sebelum dilakukan penelitian berkisar antara empat sampai enam.

b. Instrumen untuk guru selama melaksanakan proses pembelajaran, sebelum pelaksanaan penelitian adalah sebagai berikut.

1) Menurut guru, pelajaran bahasa Inggris sesungguhnya menyenangkan tetapi tidak mudah dan agak membosankan.

2) Jika diminta menggunakan bahasa Inggris dalam membelajarkan siswanya, guru agak ragu-ragu dan tidak siap.

3) Jika diminta menggunakan lagu-lagu dan media atau alat peraga dalam membelajarkan siswanya, guru agak ragu-ragu dan tidak siap

c. Rencana pembelajaran.

d. Soal-soal evaluasi.

e. Lagu-lagu dengan medianya yang sesuai.

2. Pelaksanaan penelitian

\section{Siklus I}

a. Perencanaan tindakan

Dari hasil observasi guru kelas membelajarkan yang dilakukan oleh dosen dan teman sejawat guru, dilakukan pada waktu persiapan penelitian, kemudian bersama-sama membuat rencana pembelajaran dengan topik "objects in the classroom". b. Pelaksanaan tindakan

Guru kelas melaksanakan membelajarkan objects in the classroom dengan menggunakan alat peraga dan nyanyian atau media and songs.

c. Observasi guru membelajarkan oleh dosen dan teman sejawat

Alat: APKG 1 dan APKG 2 untuk guru membelajarkan dan memperhatikan kondisi siswa selama belajar, serta tes tertulis untuk siswa pada akhir siklus. Hasilnya adalah sebagai berikut.

1) Sikap siswa pada saat belajar bahasa Inggris. Berdasarkan wawancara yang dilakukan oleh teman sejawat guru maka hasilnya siswa mulai senang dalam belajar bahasa Inggris, dikarenakan guru menggunakan alat peraga yang sesuai dengan topik yang diajarkan. Lebih-lebih setelah guru membelajarkan nyanyian yang lagunya sesuai dengan topik yang diajarkan yaitu lagu "this... and that is". Kemudian guru mengadakan penilaian dengan menggunakan tes formatif mencongak (dictation) untuk mengetahui apakah siswa dapat menuliskan kosakata bahasa Inggris dengan benar. Setiap kosakata diucapkan dua atau tiga kali oleh guru, kemudian siswa diberi kesempatan untuk menulisnya. Jumlah kosakata yang diteskan sebanyak 10 kosakata.

2) Hasil belajar. Berdasarkan tes yang diberikan pada siklus satu (terlampir), hasil rata-rata siswa adalah 6,8.

d. Refleksi

Dari hasil temuan pada siklus I, tim peneliti bersama-sama menentukan tindakan yang akan dilakukan pada siklus berikutnya yaitu siklus kedua, yaitu pembelajaran bahasa Inggris dengan menggunakan alat peraga dan nyanyian, tentang fruits atau buah-buahan.

\section{Siklus II}

1. Perencanaan tindakan

Dari hasil observasi, evaluasi, dan refleksi pada siklus I, dibuat rencana perbaikan dengan menggunakan pendekatan nyanyian dibantu dengan alat peraga. Dalam pembelajarannya guru menanamkan konsep kosakata dibantu dengan alat peraga, guru 
memberikan drill atau mengucapkan kosakata yang diulang-ulang dan siswanya menirukan sampai pengucapan bahasa Inggrisnya benar. Setelah itu, guru membelajarkan menyanyi di mana isi liriknya atau kosakatanya sesuai dengan yang diajarkan sebelumnya. Dalam membelajarkan menyanyi ini diulang-ulang sampai semua siswanya dapat menyanyikan lagu itu. Setelah itu, guru menyuruh anak-anak yang mau menyanyi ke depan kelas, baik secara perorangan, berdua ataupun bertiga. Dengan melalui bernyanyi siswa tidak merasa bahwa mereka dapat melafalkan dan menghafalkan kosakata bahasa Inggris dengan benar.

\section{Pelaksanaan tindakan}

Guru kelas melaksanakan pembelajaran dengan pendekatan bernyanyi dibantu dengan alat peraga, yaitu dengan cara menanamkan konsep kosakata melalui drill yang diulang-ulang. Kemudian diteruskan dengan bernyanyi sehingga siswa benarbenar dapat mengucapkan kosakata bahasa Inggris secara benar. Setelah itu, siswa disuruh menyanyikan sendiri di depan kelas atau mendemonstrasikan secara bergantian.

3. Observasi guru membelajarkan

Observasi guru membelajarkan dilakukan oleh dosen dan teman sejawat. Memperhatikan dan mencatat proses pembelajaran guru membelajarkan dan juga memperhatikan kondisi siswa selama belajar, serta memberikan tes tertulis untuk siswa pada akhir siklus.

Hasilnya adalah sebagai berikut.

a. Sikap siswa pada saat belajar bahasa Inggris. Berdasarkan wawancara yang dilakukan oleh teman sejawat guru maka hasilnya ialah siswa lebih senang dan antusias dalam mengikuti pembelajaran. Siswa dapat menjawab pertanyaan guru dengan benar, misalnya guru menunjuk gambar yang ada di alat peraga, siswa dapat melafalkan dengan benar padahal di alat peraga itu tidak ada tulisannya. Jadi dengan melihat gambar saja siswa dapat menyebutkan nama bendanya dalam bahasa Inggris dengan benar. b. Hasil belajar. Berdasarkan tes yang diberikan pada siklus dua maka nilai rata-rata siswa adalah 7,2.

\section{Refleksi}

Dari hasil temuan pada siklus II, tim peneliti bersama-sama menentukan tindakan yang akan dilakukan pada siklus tiga, yaitu pembelajaran bahasa Inggris dengan pendekatan bernyanyi dan media tentang animals.

\section{Siklus III}

\section{Perencanaan tindakan}

Dari hasil observasi, evaluasi, dan refleksi pada siklus II, dibuat rencana perbaikan dengan menggunakan pendekatan nyanyian dibantu dengan alat peraga.

2. Pelaksanaan tindakan

Membelajarkan dengan pendekatan nyanyian dengan media.

3. Observasi guru membelajarkan oleh dosen dan teman sejawat

Observasi terhadap proses pembelajaran, untuk guru dan siswa. Evaluasi untuk siswa berupa tes tertulis. Hasilnya adalah sebagai berikut.

a. Sikap siswa pada saat belajar bahasa Inggris. Berdasarkan wawancara yang dilakukan oleh teman sejawat guru maka hasilnya adalah siswa semakin senang atau bergairah dalam mengikuti pembelajaran bahasa Inggris, hal ini dapat dilihat dengan adanya peningkatan hasil tes tertulis dari para siswanya.

b. Hasil belajar. Berdasarkan tes yang diberikan pada siklus III maka nilai rata-rata siswa adalah 7,8 .

\section{Refleksi}

Merupakan hasil diskusi tim peneliti untuk menganalisis hasil penelitian.

Nilai rata-rata hasil belajar bahasa Inggris dalam pelaksanaan penelitian dari siklus I, II, dan III dapat digambarkan ke dalam bentuk diagram batang sebagai berikut.

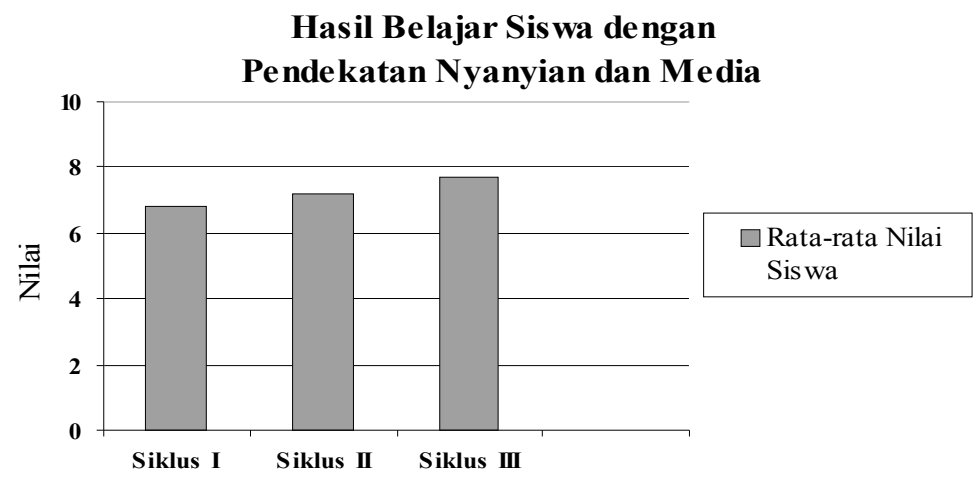

Gambar 2. Hasil belajar siswa 


\section{KESIMPULAN}

Dari uraian di atas tentang hasil penelitian maka dapat disimpulkan sebagai berikut.

1. Penelitian dianggap berhasil karena:

a. ada perubahan positif antara sikap siswa sebelum dan sesudah dilakukan penelitian, yang ditandai dengan adanya perubahan hasil belajar pada setiap siklusnya; dan

b. lebih dari $80 \%$ dari jumlah siswa mendapatkan nilai lebih besar dari 60 .

2. Pelajaran bahasa Inggris bagi siswa sebetulnya dianggap sebagai pelajaran yang:

a. menarik dan menyenangkan apabila guru membelajarkannya dengan melalui nyanyian dan media, dan

b. siswa menginginkan setiap pembelajaran guru sebaiknya menggunakan media dan bernyanyi. Pelajaran bahasa Inggris bagi guru-guru adalah pelajaran yang penting tetapi keberatan dalam membuat alat peraga dan tidak menguasai lagu anakanak, terutama lagu-lagu yang menggunakan teks bahasa Inggris.

Berdasarkan hasil belajar yang terdapat pada diagram batang di atas maka penerapan pembelajaran bahasa Inggris dengan menggunakan nyanyian dan media gambar dikatakan berhasil.

\section{DAFTAR PUSTAKA}

Arikunto, S. dkk. (2006). Penelitian tindakan kelas. Jakarta: Sinar Grafika Offset.

Burden, P.R. \& Byrd, D. M. (1999). Methods for effective teaching. Boston: Allyn \& Bacon.
Depdikbud Kantor Wilayah Daerah Khusus Ibu Kota Jakarta. (1993). Kurikulum muatan lokal pendidikan dasar: GBPP bahasa inggris sekolah dasar. Jakarta: Depdikbud.

Hanlon, R.Y. et.al. (2004). Hip hip hooray: Teacher's edition. USA: Longman.

Jalal, F. (2006, 17 September). Kompetensi guru yang diharapkan masa kini. Jakarta: Kompas.

Morris, C.G. (1990). Psychology an introduction. New Jersey: Prentice-Hall, Inc.

Rusgianto. (1998). Peningkatan kualitas pembelajaran. Jakarta: Departemen Pendidikan Nasional.

Subyakto. (1986). Metode, teknik, dan media pengajaran bahasa Inggris. Jakarta: Pusat Pengembangan Penataran Guru Bahasa Direktorat Jenderal Pendidikan Dasar dan Menengah Departemen Pendidikan dan Kebudayaan.

Tantra, D.K. (2005). Konsep dasar dan karakteristik penelitian tindakan kelas (PTK). Batam: Direktorat Jenderal Pendidikan Tinggi Departemen Pendidikan Nasional.

UU RI Nomor 14 Tahun 2005 Tentang Guru dan Dosen. (2006). Yogyakarta: Pustaka Pelajar.

Wibawa, B. \& Mukti, F. (1992). Media pengajaran. Jakarta: Ditjendikti Depdikbud PPTK.

Winkel, W.S. (1991). Psikologi pengajaran. Jakarta: Grasindo.

\section{KETERANGAN PENULIS}

Buasim, M.Pd., dilahirkan di Porbolinggo, Februari 1945. Saat ini menjabat sebagai dosen tetap di PGSD FIP UNJ. Karya ilmiah terbarunya yaitu Kiat-kiat Belajar Bahasa Inggris (2005). 